\title{
Article \\ Glyphosate Resistance Confirmation and Field Management of Red Brome (Bromus rubens L.) in Perennial Crops Grown in Southern Spain
}

\author{
José G. Vázquez-García ${ }^{1, *}$, Patricia Castro ${ }^{2} \oplus$, Hugo E. Cruz-Hipólito ${ }^{3}$, Teresa Millan ${ }^{2}$, \\ Candelario Palma-Bautista ${ }^{1}$ (D) and Rafael De Prado ${ }^{1, *(D)}$ \\ 1 Department of Agricultural Chemistry and Edaphology, University of Cordoba, 14071 Cordoba, Spain; \\ z82pabac@uco.es \\ 2 Department of Genetics, University of Cordoba, 14071 Cordoba, Spain; patricia.castro@uco.es (P.C.); \\ teresa.millan@uco.es (T.M.) \\ 3 President of Sociedad Mexicana de la Ciencia de la Maleza (SOMECIMA), Av. Vallarta 6503, Ciudad Granja, \\ Zapopan 45010, Mexico; cruzhipolito@yahoo.com.mx \\ * Correspondence: z82vagaj@uco.es (J.G.V.-G.); qe1pramr@uco.es (R.D.P.)
}

\section{check for}

updates

Citation: Vázquez-García, J.G. Castro, P.; Cruz-Hipólito, H.E.; Millan, T.; Palma-Bautista, C.; De Prado, R. Glyphosate Resistance Confirmation and Field Management of Red Brome (Bromus rubens L.) in Perennial Crops Grown in Southern Spain. Agronomy 2021, 11, 535. https://doi.org/10.3390/ agronomy11030535

Academic Editor: Donato Loddo

Received: 24 January 2021

Accepted: 10 March 2021

Published: 12 March 2021

Publisher's Note: MDPI stays neutra with regard to jurisdictional claims in published maps and institutional affiliations.

Copyright: (C) 2021 by the authors Licensee MDPI, Basel, Switzerland. This article is an open access article distributed under the terms and conditions of the Creative Commons Attribution (CC BY) license (https:// creativecommons.org/licenses/by/ $4.0 /)$.

\begin{abstract}
The excessive use of the herbicide glyphosate on annual and perennial crops grown in Southern Spain has caused an increase in resistant weed populations. Bromus rubens has begun to spread through olive and almond cultivars due to low glyphosate control over these species, whereas previously it had been well controlled with field dose $\left(1080 \mathrm{~g}_{\text {ae ha }}{ }^{-1}\right)$. Characterization using Simple Sequence Repeat (SSR) markers confirmed the presence of B. rubens collected in Andalusia. A rapid shikimic acid accumulation screening showed 17 resistant $(\mathrm{R})$ populations with values between 300 and $700 \mu \mathrm{g}$ shikimate $\mathrm{g}^{-1}$ fresh weight and three susceptible (S) populations with values between 1200 and $1700 \mu \mathrm{g}$ shikimate $\mathrm{g}^{-1}$ fresh weight. In dose-response experiments the $\mathrm{GR}_{50}$ values agreed with previous results and the resistance factors (RFs: $\mathrm{GR}_{50} \mathrm{R} / \mathrm{GR}_{50} \mathrm{~S}(\mathrm{Br} 1)$ ) were between $4.35(\mathrm{Br} 9)$ and 7.61 (Br19). Foliar retention assays shown no differences in glyphosate retention in both $\mathrm{R}$ and $\mathrm{S}$ populations. The tests carried out in a resistant field (Br10) demonstrated the control efficacy of preemergence herbicides since flazasulfuron in the tank mix with glyphosate had up to $80 \%$ control 15 to 120 days after application (DAA) and grass weed postemergence herbicides, such as propaquizafop + glyphosate and quizalofop + glyphosate, had up to $90 \%$ control 15 to 90 DAA. Results confirm the first scientific report of glyphosate-resistant $B$. rubens worldwide; however, the use of herbicides with another mode of action (MOA) is the best tool for integrated weed management.
\end{abstract}

Keywords: Bromus spp.; glyphosate resistance; integrated weed management; crop protection

\section{Introduction}

Weed control has been performed by the application of multiples herbicides with different modes of action (MOAs) since the 1940s [1]. Specifically, the herbicide glyphosate (N-(hosphonomethyl)glycine) has been commercialized worldwide since the 1970s and is used as a broad-spectrum and postemergence treatment for weed control due to its translocation ability in plants [2]. The MOA of glyphosate is by aromatic amino acids biosynthesis inhibition [3]. The broad-spectrum activity of this herbicide is due to the inhibition of 5-enolpyruvyl-3-shikimate phosphate synthase (EPSPS), which is present in all plants [4]. The EPSPS enzyme acts in the shikimic acid pathway in the biosynthesis of aromatic amino acids, such as phenylalanine, tyrosine, and tryptophan [5]. These amino acids are essential for plants and when they are inhibited by the action of glyphosate all susceptible plants die.

Nowadays, it is know that the weed resistance is the consequence of selection pressure by farmers coupled with the high evolution capacity of weed populations [6]. The resistant 
populations shown a selective-evolutive advantage over other weed species treated with herbicides, which increase the potential of the establishment of resistant weeds $[7,8]$. Thus, one consequence of the widespread usage of glyphosate for weed control (as a unique control tool) has been the evolution of glyphosate-resistant (G-R as from now) weeds [9,10]. This represents a dramatic scenario because growers should be increasing the rate doses or changing to other herbicides to obtain satisfactory control over weed populations [11]. There have been reports of G-R in grass weeds since the 1990s [12]. Recently, 52 species were classified as G-R, 26 of which were monocotyledons of various genera, including Bromus spp. Although this list includes B. catharticus (2017), B. diandrus (2011), and Bromus rubens (2014) [13], there are only two publications with established resistance parameters B. diandrus [14] in Southern Australia (AU) and B. sterilis [15] in the United Kingdom (UK).

Bromus L. is a large genus of the Poaceae family which comprises around 160 annual and perennial species [16]. This genus is distributed worldwide and is well known for being taxonomically complex $[16,17]$ because of important morphological variations, plasticity, and hybridization [18]. In the Mediterranean region, B. rubens L. ((syn.: Anisantha rubens (L.) Nevski, B. madritensis L. subsp. rubens (L.) Husnot) (Medit.)), also known as red brome, is an important winter-annual grass weed [19]. This species has typical brush-like condensed panicles that are markedly different from Bromus madritensis L. [20]. B. rubens and B. madritensis are successful colonizers in North America and other countries [21]. In Spain, farmers sometimes use it as a cover crop with perennial crops, such as olive and almond. Soil erosion is one of the most important problems in Mediterranean agriculture. In the 1990s, it was concluded that cultivation with cover crops is of great interest in olive and almond groves with soils at a special risk of erosion. The soil losses in perennial crops on slopes are around 10 to $50 \mathrm{t} \mathrm{ha}^{-1}$ year $^{-1}$ [22].

Regarding integrated weed management, cover crops are an important tool for control of weed species and erosion soil. However, another type of control is also necessary. With the aim of establishing the use of herbicides as rapid and effective tools in control of weed populations, farmers should incorporate pre- and postemergence herbicides to manage them in olive and almond crops. In the last four decades, the most frequently used herbicides have been Photosystem II and I (PS II and I), Acetolactate synthase (ALS), Acetyl CoA Carboxylase (ACCase), Glutamine synthase (GS), and EPSPS inhibitors [22,23].

B. rubens has been maintained principally by mechanical mowing and herbicides such as arloxyphenoxypropionate (FOP) and glyphosate (ACCase and EPSPS inhibitors, respectively). In 2018, farmers in Southern Spain reported failures in the field B. rubens control. Because glyphosate was used for weed control in olive and almond crops for many years, we hypothesized that $B$. rubens may have been selected as resistant. The concern of this scenario is serious because there are not many herbicides capable of such effective control and low cost as glyphosate.

Due to the complexity and adaptative attributes of the Bromus genus, the aims of this work were: (a) discriminate different species of the Bromus genus using molecular markers; (b) confirm B. rubens G-R in Spain using rapid shikimic acid accumulation and dose-response bioassays; (c) search directly in an almond field for alternative herbicide control with different MOAs.

\section{Materials and Methods}

\subsection{Plant Material}

In 2018, glyphosate application had poor control of B. rubens present in different perennial crops in Andalusia, Spain, mainly in the provinces of Cordoba, Malaga, and Granada. Twenty populations were harvested from different fields with/without history of glyphosate treatments. The populations were separated and labeled in paper envelopes and taken into a cold chamber $\left(4^{\circ} \mathrm{C}\right.$ day /night) until further assays (Table 1$)$. For germination, the seeds were placed in trays $(15 \times 15 \times 5 \mathrm{~cm})$ with previously humidified peat-moss and trays were placed in a cold chamber for $48 \mathrm{~h}$. After this time, they were taken to a growth 
chamber $\left(26 / 18{ }^{\circ} \mathrm{C}\right.$ day/night) with $60 \%$ relative humidity and $12 \mathrm{~h}$ of light density at $850 \mathrm{mmol} \mathrm{m}^{-2} \mathrm{~s}^{-1}$.

Table 1. Characteristics of Bromus rubens populations used in this work, code assigned to each population, history of application, and coordinates.

\begin{tabular}{ccccc}
\hline Code & Location & Crops & History of Application (Years) ${ }^{\text {a }}$ & Coordinates \\
\hline Br1 & Malaga & Young olive & organic & $37.105500,-4.551778$ \\
Br2 & Cordoba & Orchard & $>10$ & $37.646157,-4.311400$ \\
Br3 & Granada & Railway & Tank mix b & $37.389201,-3.582310$ \\
Br4 & Granada & Orchard & 20 & $37.394245,-3.566320$ \\
Br5 & Granada & Orchard & $>15$ & $37.393319,-3.564946$ \\
Br6 & Cordoba & Almond & $>10$ & $37.736953,-4.645727$ \\
Br7 & Cordoba & Almond & $>15$ & $37.737263,-4.645049$ \\
Br8 & Cordoba & Orchard & $>15$ & $37.708111,-4.789167$ \\
Br9 & Granada & Orchard & $10-15$ & $37.394377,-3.570889$ \\
Br10 & Cordoba & Almond & $>15$ & $37.737492,-4.646091$ \\
Br11 & Cordoba & Young olive & 3 & $37.681839,-4.632792$ \\
Br12 & Granada & Orchard & $10-15$ & $37.393853,-3.572896$ \\
Br13 & Cordoba & No crop & $>15$ & $37.631281,-4.280830$ \\
Br14 & Cordoba & Orchard & $>15$ & $37.710540,-4.790917$ \\
Br15 & Cordoba & Orchard & $10-15$ & $37.707483,-4.789220$ \\
Br16 & Malaga & Olive & $>15$ & $36.983067,-4.950822$ \\
Br17 & Malaga & Olive & $>15$ & $36.979917,-4.939506$ \\
Br18 & Malaga & Olive & $10-15$ & $37.035831,-4.590087$ \\
Br19 & Malaga & Olive & 20 & $36.978790,-4.649318$ \\
Br20 & Malaga & Olive & 20 & $37.051456,-4.354452$ \\
\hline
\end{tabular}

a Years using glyphosate; during the last 10 years, farmers declared use of other herbicides such as oxyfluorfen (Protoporphyrinogen Oxidase (PPO) inhibitor) or flazasulfuron (Acetolactate Synthase (ALS) inhibitor) in tank mixtures with glyphosate. ${ }^{\mathrm{b}}$ Mix of herbicides to control grasses and broadleaf plants.

Seedlings of the 20 populations were transplanted into pots (one plant plot $^{-1}$ ) with $240 \mathrm{~g}$ of substrate (soil:peat moss (1:1)) that was previously irrigated. All populations were transferred to a greenhouse and watered daily to field capacity before and during assays.

\subsection{Molecular Characterization of Bromus spp.}

Four populations previously identified as B. sterilis, B. tectorum, B. diandrus, and B. madritensis [24] plus twenty populations of $B$. rubens identified in situ were used for molecular characterization. A total of 24 populations were characterized using Simple Sequence Repeat (SSR) markers following the methodology described by Ramakrishnan et al. [25] with some modifications. For this step, ten individuals from each population were used. Samples of $\sim 100 \mathrm{mg}$ of young leaf tissue from each plant at $\mathrm{BBCH} 13-14$ stage [26] were taken to obtain DNA. Forward primers were tailed with the M13 sequence (5'-TGTAAAACGACGCCAGT- $\left.3^{\prime}\right)$ at the $5^{\prime}$ ends for fluorescent labelling of PCR fragments [27]. Amplification of DNA was carried out in a $15 \mu \mathrm{L}$ reaction mixture containing $20 \mathrm{ng}$ of DNA, $5 x$ Buffer (50 mM KCl, $10 \mathrm{mM}$ Tris-HCl, $0.1 \%$ Triton X-100), $2.5 \mathrm{mM} \mathrm{MgCl}$, $250 \mu \mathrm{M}$ of dNTPs, $0.1 \mu \mathrm{M}$ of forward primer, $0.4 \mu \mathrm{M}$ of reverse primer, $0.4 \mu \mathrm{M}$ of 6-FAM, and 0.25 units of Taq DNA polymerase (BIOTOOLS). PCR reactions were performed in a Biometra ${ }^{\circledR}$ thermocycler and conditions of the PCR amplification were as follows: one cycle of $15 \mathrm{~min}$ at $95^{\circ} \mathrm{C}$, then 40 cycles of $30 \mathrm{~s}$ at $95^{\circ} \mathrm{C}, 30 \mathrm{~s}$ at $60^{\circ} \mathrm{C}$, and $30 \mathrm{~s}$ at $72{ }^{\circ} \mathrm{C}$, followed by 8 cycles of $30 \mathrm{~s}$ at $90^{\circ} \mathrm{C}, 45 \mathrm{~s}$ at $53^{\circ} \mathrm{C}$, and $45 \mathrm{~s}$ at $72{ }^{\circ} \mathrm{C}$, and one final extension step of $10 \mathrm{~min}$ at $72^{\circ} \mathrm{C}$. Subsequently, the PCR products were separated using an automatic capillary sequencer (ABI 3130 Genetic Analyzer Applied Biosystems, Madrid/HITACHI, Madrid, Spain) from the University of Cordoba, Spain. The results were analyzed using Genotyper software 3.7 (Applied Biosystems). A DNA standard (400HD-ROX) was used to calculate the size of the amplified PCR fragments (alleles) for each SSR marker alleles. Genetic distances between all individuals were calculated using Jaccard's coefficient of 
similarity. Grouping of the genotypes was determined using the unweighted pair group method with arithmetic mean (UPGMA) and a dendrogram was generated with the NTSYS program [28].

\subsection{Resistant Fast Screening by Shikimic Acid Accumulation Assay}

The main objective of this assay was to differentiate resistant and susceptible populations, knowing that the increase in shikimic acid accumulation referred to the action of glyphosate and therefore, were considered susceptible (S). However, those populations that accumulated very little or nothing were labeled as resistant $(R)$. Discs were cut from the youngest leaf of ten plants and then were pooled. In total, $50 \mathrm{mg}$ from each mix per population was transferred into $2 \mathrm{~mL}$ Eppendorf tubes containing $999 \mu \mathrm{L}$ of monoammonium phosphate $\left(\mathrm{NH}_{4} \mathrm{H}_{2} \mathrm{PO}_{4} 10 \mathrm{mM}, \mathrm{pH} 4.4\right)$ plus $1 \mu \mathrm{L}$ of glyphosate $(1000 \mu \mathrm{M})$. The shikimic acid accumulation was performed according to methodology described by Vázquez-García et al. [29] with some modifications. Four treated replications and four nontreated samples were used in a completely random design test. Finally, the results were indicated in $\mu \mathrm{g}$ of shikimic acid $\mathrm{g}^{-1}$ fresh tissue.

\subsection{Glyphosate Dose-Response Curves Assay}

Whole plants at $\mathrm{BBCH} 13-14$ stage [26] of each population were treated with glyphosate (Roundup Energy ${ }^{\circledR}$ SL, $45 \%$ as isopropylamine salt, Monsanto) doses ranging from 0 to $3000 \mathrm{~g}_{\mathrm{ge} \mathrm{ha}}{ }^{-1}$. Herbicide application was performed by chamber (SBS-060 De Vries Manufacturing, Hollandale, MN, United States) equipped with an 8002 flat fan nozzle delivering $200 \mathrm{~L} \mathrm{ha}^{-1}$ at $250 \mathrm{KPa}$. After application, the plants were taken into the greenhouse and irrigated daily as necessary. Ten replications (one plant $=$ one replication) per glyphosate dose were used in a completely random design test. At 21 days after application, the survival plants were evaluated to estimate the lethal dose to kill $50 \%$ of population $\left(\mathrm{LD}_{50}\right)$. In addition, plants were weighed after dried them at $60^{\circ} \mathrm{C}$ for $48 \mathrm{~h}$. Subsequently, the dose that inhibits the plant growth to $50 \%\left(\mathrm{GR}_{50}\right)$ was estimated.

\subsection{Glyphosate Foliar Retention Assay}

The retention experiment was performed in six plants of each B. rubens population. According to González-Torralva et al. [30], a glyphosate dose of $360 \mathrm{~g}_{\text {ae ha }}{ }^{-1}$ plus $100 \mathrm{mg} \mathrm{L}^{-1}$ $\mathrm{Na}$-fluorescein was applied to $B$. rubens plants. The treatment equipment was described in the previous section. Two hours after application, the plants were cut and transferred to test tubes which contained $50 \mathrm{~mL}$ of $5 \mathrm{mM} \mathrm{NaOH}$. Then, test tubes were shaken for $30 \mathrm{~s}$ to remove the spray solution. Subsequently, the washed solution was transferred to glass vials to measure the fluorescein absorbance; for this step, a spectrofluorometer (Hitachi F-2500, Tokyo, Japan) with an excitation wavelength of $490 \mathrm{~nm}$ and absorbance at $510 \mathrm{~nm}$ was used. Finally, plants were weighed after $48 \mathrm{~h}$ at $60^{\circ} \mathrm{C}$ drying. A completely randomized design was performed with two repetitions (one repetition $=$ six plants per population). The results are expressed in $\mu \mathrm{L}$ spraying solution per gram dry matter.

\subsection{Chemical Alternatives In Situ}

This trial was carried out during two growing seasons at winter-spring time (20182019 and 2019-2020) in a field where some G-R populations originated. In "La Reina" $(37.737492,-4.646091)$, almond groves infested with B. rubens ( $80 \%$ infestation) were treated with glyphosate and other herbicides (Table 2) to test their performances. A randomized complete block design with four replications was used. The herbicide treatments were performed in plots of $10 \mathrm{~m}^{2}$ at two different stages: (a) pre-emergence and (b) postemergence. A Pulverex backpack sprayer equipped with four flat fan nozzles Teejet 11002, at a spraying pressure of $200 \mathrm{kPa}$ and calibrated to deliver a volume of $200 \mathrm{~L} \mathrm{ha}^{-1}$ was used for applications. The control was evaluated 30, 60, 90, and 120 days after application (DAA) at pre- and 30,60, and 90 DAA at postemergence stages for the percentage of 
effectiveness in B. rubens control. Control ratings were expressed on a 0 (no control) to 100 (plant dead) scale.

Table 2. Herbicide treatments tested in situ for control effectiveness of glyphosate-resistant Bromus rubens in field.

\begin{tabular}{|c|c|c|c|}
\hline Active Ingredient ${ }^{a}$ & Commercial Name ${ }^{b}$ & Doses (g ae/ai ha ${ }^{-1}$ ) & Timing \\
\hline Untreated & - & - & - \\
\hline Flazasulfuron + glyphosate & Terafit $^{\circledR}$ WG + Roundup Energy ${ }^{\circledR}$ SL & $50+1080$ & Pre-emergence \\
\hline $\begin{array}{l}\text { Diflufenican + iodosulfuron }+ \\
\text { glyphosate }\end{array}$ & Musketeer ${ }^{\circledR}$ OF + Roundup Energy ${ }^{\circledR}$ SL & $150+10+1080$ & Pre-emergence \\
\hline Chlorotoluron + diflufenican & Anibal $^{\circledR} \mathrm{SC}$ & $1800+113$ & Pre-emergence \\
\hline Diflufenican + glyphosate & Zarpa ${ }^{\circledR} \mathrm{SC}$ & $280+1120$ & Pre-emergence \\
\hline Glyphosate & Roundup Energy ${ }^{\circledR}$ SL & 1080 & Postemergence \\
\hline Glyphosate & Roundup Energy ${ }^{\circledR}$ SL & 1800 & Postemergence \\
\hline Flazasulfuron + glyphosate & Chikara Duo ${ }^{\circledR}$ WG & $20+860$ & Postemergence \\
\hline Glyphosate + propaquizafop & Roundup Energy ${ }^{\circledR} \mathrm{SL}+$ Ágil $^{\circledR} \mathrm{EC}$ & $1080+150$ & Postemergence \\
\hline Glyphosate + quizalofop & Roundup Energy ${ }^{\circledR} \mathrm{SL}+$ Leopard $^{\circledR} \mathrm{EC}$ & $1080+100$ & Postemergence \\
\hline
\end{tabular}

${ }^{a}$ (Flazasulfuron (Terafit ${ }^{\circledR}, 25 \%$ WG, Syngenta, Spain); Glyphosate (Roundyp Energ ${ }^{\circledR}, 45 \%$ p/v. SL, Monsanto, Spain); Diflufenican + glyphosato (Musketeer ${ }^{\circledR}, 15 \% \mathrm{p} / \mathrm{v}$. diflufenican $+1 \% \mathrm{p} / \mathrm{v}$. iodosulfuron-methyl, OF, Bayer CropScience, Sapain); Chlorotoluron + diflufenican (Anibal ${ }^{\circledR} .40 \% \mathrm{p} / \mathrm{v}$. chlorotoluron $+2.5 \% \mathrm{p} / \mathrm{v}$. diflufenican, SC, ADAMA, Spain); Diflufenican + glyphosate (Zarpa ${ }^{\circledR}, 4 \% \mathrm{p} / v$. diflufenican + $16 \% \mathrm{p} / \mathrm{v}$. glyphosate, SC, BASF Agro, Spain); Flazasulfuron + glyphosate (Chikara Duo ${ }^{\circledR}, 6.7 \mathrm{~g} \mathrm{~kg}^{-1}$ flazasulfuron $+288 \mathrm{~g} \mathrm{~kg}{ }^{-1} \mathrm{glifosato}$ WG, Belchim Crop Protection, Spain); Propaquizafop (Agil ${ }^{\circledR}, 10 \% p / v$, EC, ADAMA, Spain); Quizalofop (Leopard ${ }^{\circledR}, 5 \%$ p $/ v$, EC ADAMA, Spain). ${ }^{b}$ WG: water dispensable granules; SL: Soluble concentrate; OF: Oil miscible flowable concentrate; SC: Suspension concentrate; EC: Emulsifiable concentrate.

\subsection{Statistical Analyses}

Parameters $\mathrm{GR}_{50}$ and $\mathrm{LD}_{50}$ described in dose-response curve assays were estimated with a nonlinear regression using Equation (1).

$$
\mathrm{Y}=\mathrm{c}+\{(\mathrm{d}-\mathrm{c}) /[1+(\mathrm{x} / \mathrm{g}) \mathrm{b}]\}
$$

where $\mathrm{Y}$ is the dry weight, or plant mortality expressed as a percentage of the value for the untreated control, $\mathrm{c}$ and $\mathrm{d}$ are the coefficients corresponding to the lower (fixed at 0 ) and upper asymptotes, respectively, $b$ is the slope of the curve point (i.e., $\mathrm{GR}_{50}, \mathrm{LD}_{50}$ ), $\mathrm{x}$ (independent variable) is the glyphosate doses, and $g$ is the herbicide rate at the point of inflection curve. The nonlinear regression analyses were conducted using the $\mathrm{R}$ package "drc" [31].

In addition, $\mathrm{GR}_{50}$ and $\mathrm{LD}_{50}$ resistance factor (RF) was calculated with Equation (2).

$$
\mathrm{RF}=\left(\mathrm{GR}_{50} \text { or } \mathrm{LD}_{50} \mathrm{R} / \mathrm{GR}_{50} \text { or } \mathrm{LD}_{50} \mathrm{~S}\right)
$$

where " $\mathrm{R}$ " is the resistant population and " $\mathrm{S}$ " is susceptible population.

For the rest of experiments, the normal error distribution and the homogeneity of the variance were verified for each set. Finally, data were assessed via analysis of variance (ANOVA) using the Statistix software version 10.0 (Analytical software, Tallahassee, FL, USA). A Tukey $(p<0.05)$ test was conducted to compare the means.

\section{Results}

\subsection{Bromus spp. Molecular Characterization}

Seven SSR markers (Bt03, Bt04, Bt05, Bt12, Bt26, Bt30 and Bt33) were enough to discriminate the Bromus species tested. The dendrogram shows five groups at a similarity coefficient of 0.5 (Figure 1). Group I was formed by B. sterilis individuals. The second group corresponded to B. rubens and included the 20 populations from Andalusia. All B. rubens populations grouped together regardless of the province where they were collected, and $\mathrm{R}$ and $S$ individuals could not be distinguished by the seven SSR markers used in this study. B. diandrus and B. madritensis were differentiated in groups III and IV, respectively. Finally, group $\mathrm{V}$ was comprised of the $B$. tectorum population. 


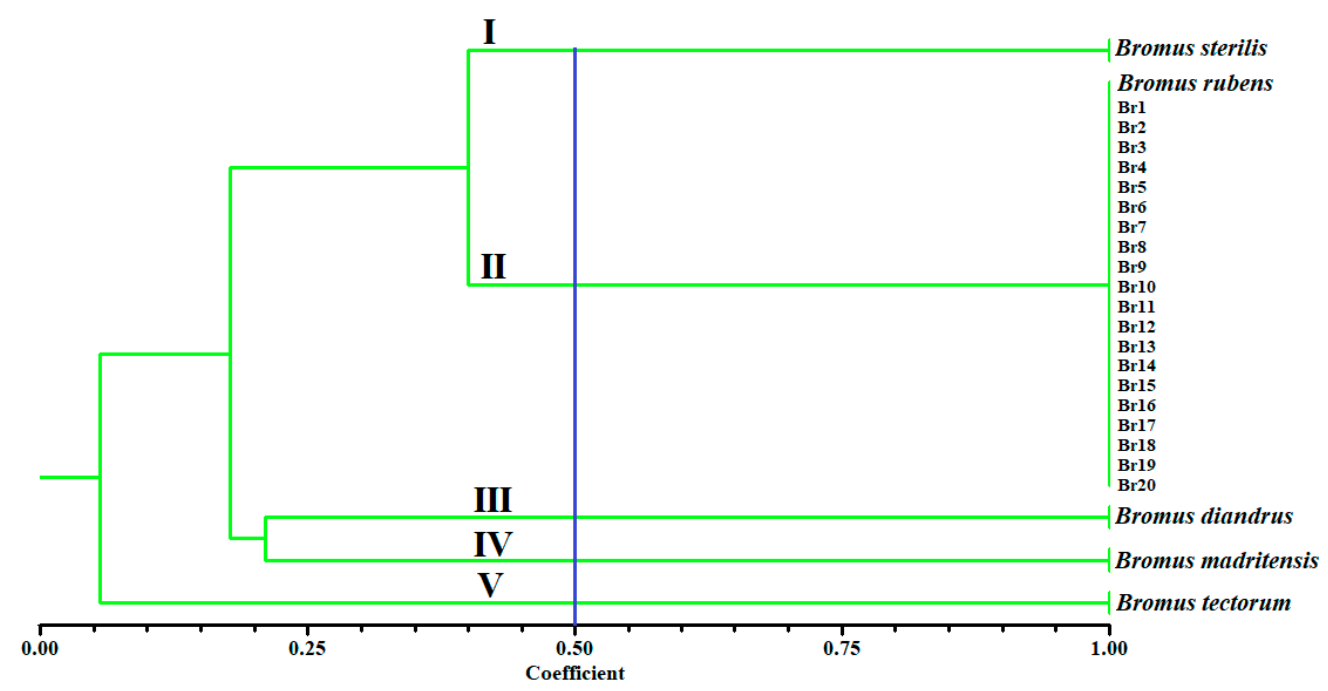

Figure 1. Dendrogram obtained from cluster analysis of 5 Bromus species (24 populations) based on Jaccard's coefficient of similarity using seven Simple Sequence Repeat (SSR) markers.

\subsection{Resistant Fast Screening by Shikimic Acid Accumulation Assay}

Overall, the $B$. rubens populations response was different, which resulted in multiple patrons of resistance to the herbicide glyphosate. This fast screening at $1000 \mu \mathrm{M}$ of glyphosate, showed 17 resistant populations out of 20, which had accumulated the least shikimic acid (Figure 2). Br1, Br3, and Br11 populations accumulated the highest amount of shikimic acid at a rate of 1200 to $1700 \mu^{g} \mathrm{~g}^{-1}$ fresh weight, whereas the other 17 populations accumulated 300 to $700 \mu \mathrm{g} \mathrm{g}^{-1}$ fresh weight.

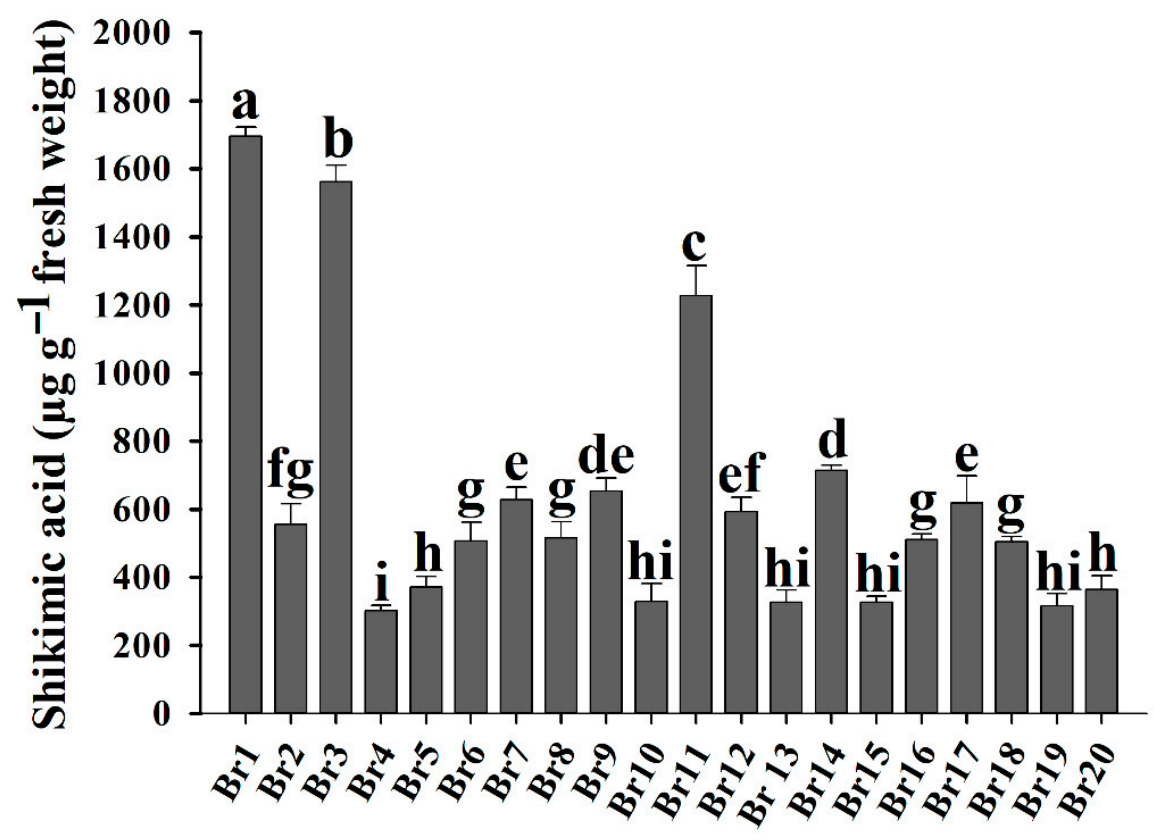

Bromus rubens populations

Figure 2. Shikimic acid accumulation of 20 Bromus rubens populations at $1000 \mu \mathrm{M}$ glyphosate. The different letters in the measurements differed statistically in the Tukey's test (95\%). 


\subsection{Glyphosate Dose-Response Curves}

The estimated dose-response curve parameters demonstrated different resistance levels in B. rubens populations (Table 3). Seventeen populations were resistant because they required at least 1080.33 to $2100.40 \mathrm{~g}$ ae ha ${ }^{-1}$ to reduce their mortality to $50 \%$, indicating that the glyphosate field dose should be doubled or even tripled for total control. Br4 and Br19 populations were the most resistant these required 2100.4 and $2024.47 \mathrm{~g}$ ae ha ${ }^{-1}$, respectively, to kill $50 \%$ of the population, whereas $\mathrm{Br} 3$ and $\mathrm{Br} 1$ populations needed only 274.22 and $229.87 \mathrm{~g}_{\text {ae }} \mathrm{ha}^{-1}$, respectively. In contrast, $\mathrm{GR}_{50}$ values showed a $\mathrm{S}$ population (Br1) needed only $140.64 \mathrm{~g}$ ae ha ${ }^{-1}$, whereas the most resistant needed $1031 \mathrm{~g}$ ae ha ${ }^{-1}$ to reduce the dry weight at $50 \%$. This meant that the RF referred to a dry weight reduction $\left(G_{50}\right)$ varying from 1.05 to 7.61 (Table 3, Figure 3). According to the RF results, we characterized 17 populations as G-R. (Figure 3).

Table 3. Dose-response parameters of Bromus rubens resistant (R) and susceptible (S) populations.

\begin{tabular}{|c|c|c|c|c|c|c|c|c|}
\hline Code & $d^{*}$ & $\mathbf{b}^{*}$ & $\mathrm{GR}_{50}\left(\mathrm{~g}\right.$ ae ha $\left.{ }^{-1}\right)$ & RF & $d^{*}$ & $\mathbf{b}^{*}$ & $\mathrm{LD}_{50}\left(\mathrm{~g}\right.$ ae ha $\left.{ }^{-1}\right)$ & RF \\
\hline Br1 & 89.92 & 4.71 & $140.64 \pm 5.86$ & - & 101.17 & 3.80 & $229.87 \pm 8.85$ & - \\
\hline $\mathrm{Br} 2$ & 96.30 & 1.66 & $856.06 \pm 54.09$ & 6.09 & 100.27 & 7.37 & $1706.78 \pm 18.78$ & 7.42 \\
\hline $\mathrm{Br} 3$ & 102.30 & 2.84 & $148.33 \pm 6.62$ & 1.05 & 102.19 & 3.26 & $274.22 \pm 7.46$ & 1.19 \\
\hline Br4 & 88.54 & 2.99 & $1031.76 \pm 55.51$ & 7.34 & 99.92 & 7.76 & $2100.40 \pm 80.12$ & 9.14 \\
\hline Br5 & 99.43 & 1.24 & $955.96 \pm 54.08$ & 6.80 & 100.62 & 5.16 & $1766.50 \pm 73.58$ & 7.68 \\
\hline Br6 & 91.57 & 2.42 & $785.70 \pm 42.36$ & 5.59 & 99.36 & 7.12 & $1427.68 \pm 18.57$ & 6.21 \\
\hline Br7 & 93.65 & 4.01 & $736.51 \pm 28.04$ & 5.24 & 98.62 & 3.20 & $1378.60 \pm 27.07$ & 6.00 \\
\hline Br8 & 89.79 & 3.39 & $875.52 \pm 35.49$ & 6.23 & 100.41 & 6.11 & $1759.61 \pm 24.00$ & 7.65 \\
\hline Br9 & 94.28 & 3.37 & $611.65 \pm 24.35$ & 4.35 & 99.84 & 5.32 & $1284.82 \pm 25.16$ & 5.59 \\
\hline Br10 & 99.03 & 1.47 & $955.35 \pm 62.06$ & 6.79 & 100.27 & 1.27 & $1702.52 \pm 34.02$ & 7.41 \\
\hline Br11 & 94.70 & 1.48 & $226.21 \pm 20.95$ & 1.61 & 96.01 & 2.31 & $563.46 \pm 38.95$ & 2.45 \\
\hline $\mathrm{Br} 12$ & 93.20 & 3.23 & $634.08 \pm 26.68$ & 4.51 & 98.18 & 5.24 & $1320.45 \pm 33.26$ & 5.74 \\
\hline Br13 & 90.69 & 3.18 & $919.97 \pm 42.06$ & 6.54 & 98.64 & 8.49 & $1658.63 \pm 22.88$ & 7.22 \\
\hline Br14 & 97.60 & 1.89 & $926.95 \pm 54.08$ & 6.59 & 100.86 & 5.79 & $1570.29 \pm 26.83$ & 6.83 \\
\hline Br15 & 99.25 & 1.77 & $767.66 \pm 57.86$ & 5.46 & 99.22 & 4.77 & $1428.05 \pm 42.49$ & 6.21 \\
\hline Br16 & 95.23 & 3.96 & $855.78 \pm 27.87$ & 6.08 & 100.43 & 4.68 & $1292.96 \pm 42.77$ & 5.62 \\
\hline Br17 & 95.74 & 4.21 & $825.43 \pm 17.74$ & 5.87 & 100.33 & 3.47 & $1180.57 \pm 43.28$ & 5.14 \\
\hline Br18 & 96.68 & 4.60 & $669.84 \pm 15.58$ & 4.76 & 100.93 & 3.67 & $1080.33 \pm 36.33$ & 4.70 \\
\hline Br19 & 90.88 & 6.80 & $1070.97 \pm 33.16$ & 7.61 & 100.23 & 5.61 & $2024.47 \pm 27.90$ & 8.81 \\
\hline Br20 & 94.56 & 8.07 & $983.50 \pm 17.23$ & 7.00 & 99.00 & 6.73 & $1757.68 \pm 31.79$ & 7.65 \\
\hline
\end{tabular}

${ }^{*} \mathrm{~d}$ is the upper coefficient and $\mathrm{b}$ is the slope of the curve.

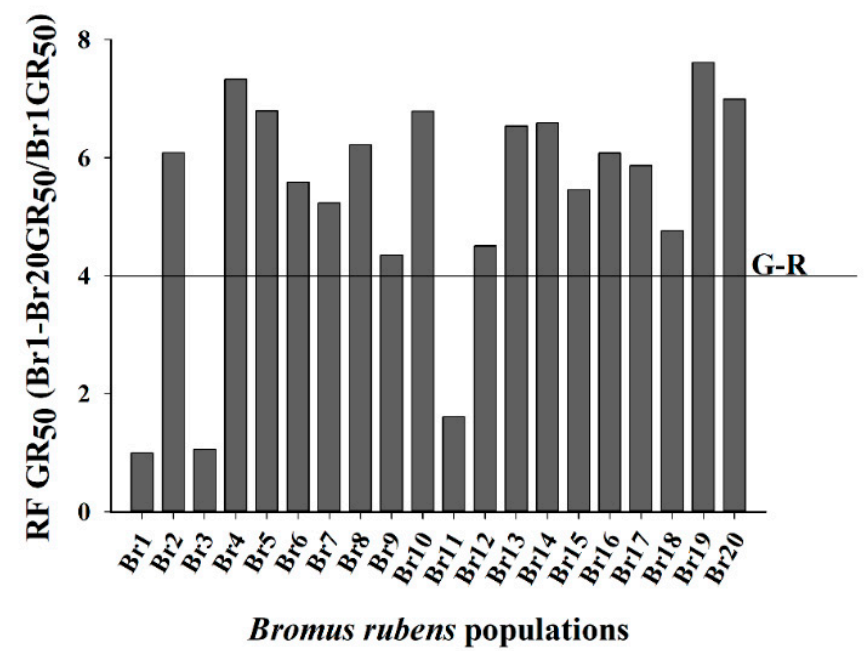

Figure 3. Calculated resistant factor of 20 Bromus rubens populations from Southern Spain. Populations above the line were considered glyphosate-resistant. 


\subsection{Foliar Retention Assay}

There were not differences between the $20 \mathrm{~B}$. rubens populations. They had values from 371.6 to $416.75 \mu \mathrm{L}$ glyphosate $\mathrm{g}^{-1}$ dry weight. Both $\mathrm{R}$ and $\mathrm{S} B$. rubens populations had no significant differences in this assay; thus, foliar retention was not involved in the low susceptibility to glyphosate.

\subsection{Chemical Alternatives In Situ}

Field trials carried out in "La Reina" (Br10 (GR 50 factor: 6.79 and $\mathrm{LD}_{50}$ factor: 7.41$)$ ) in almond trees, demonstrated the potential alternatives to glyphosate. Overall, the percentage B. rubens control was similar in the two seasons. Treatments applied pre-emergence were the least promising because only the glyphosate and flazasulfuron tank mix had the best results in both seasons (Figure 4). This treatment maintained an efficacy close to $80 \%$ $( \pm)$ against $B$. rubens from 30 DAA to 120 DAA (Figure 4). Otherwise, the application with chlorotoluron and diflufenican had the worst result, with poor control $(20 \%)$ from 30 to 120 DAA in both growing seasons. Diflufenican plus iodosulfuron and glyphosate had satisfactory control in nontarget species, such as Lolium sp., Vulpia sp., and Conyza sp. but not against $B$. rubens (Figures 4 and 5). Herbicides applied in postemergence were a more promising chemical alternative. Grass weed herbicides (ACCase inhibitors), such as propaquizafop and quizalofop in tank mix with glyphosate, controlled B. rubens up to $90 \%$ from 30 to 90 DAA (Figure 5). Additionally, this tank mix controlled other important weeds, such as Lolium sp., Hordeum murinum, and Bromus sp. Glyphosate resistance was visualized with applications at $1080 \mathrm{~g}$ (control under 60\%) and $1800 \mathrm{~g}^{2} \mathrm{a} \mathrm{ha}^{-1}$ (control close to $80 \%$ but only at $30 \mathrm{DAA})$. Flazasulfuron $\left(20 \mathrm{~g} \mathrm{ai} \mathrm{ha}^{-1}\right)$ plus glyphosate $\left(860 \mathrm{~g} \mathrm{ae} \mathrm{ha}^{-1}\right)$ is a commercial product (Chikara Duo ${ }^{\circledR}$ ) that showed to be a good treatment, but only for the first 30 DAA, after which time B. rubens control was poor (Figure 4).

\section{8-2019}
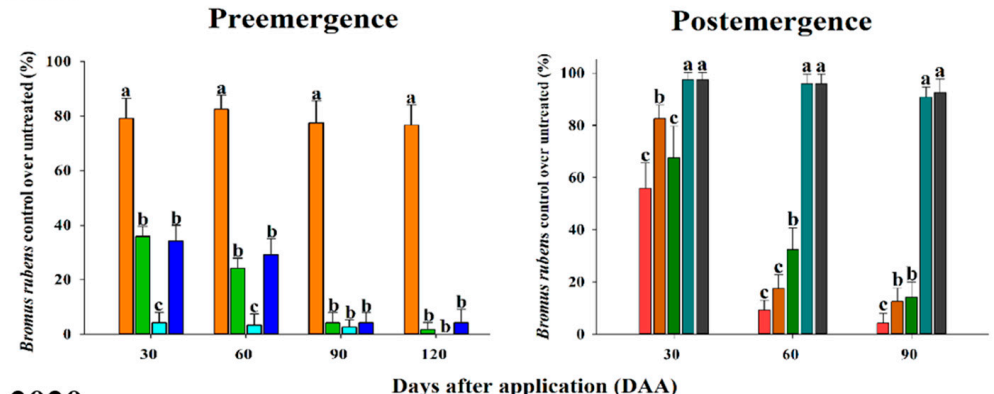

2019-2020

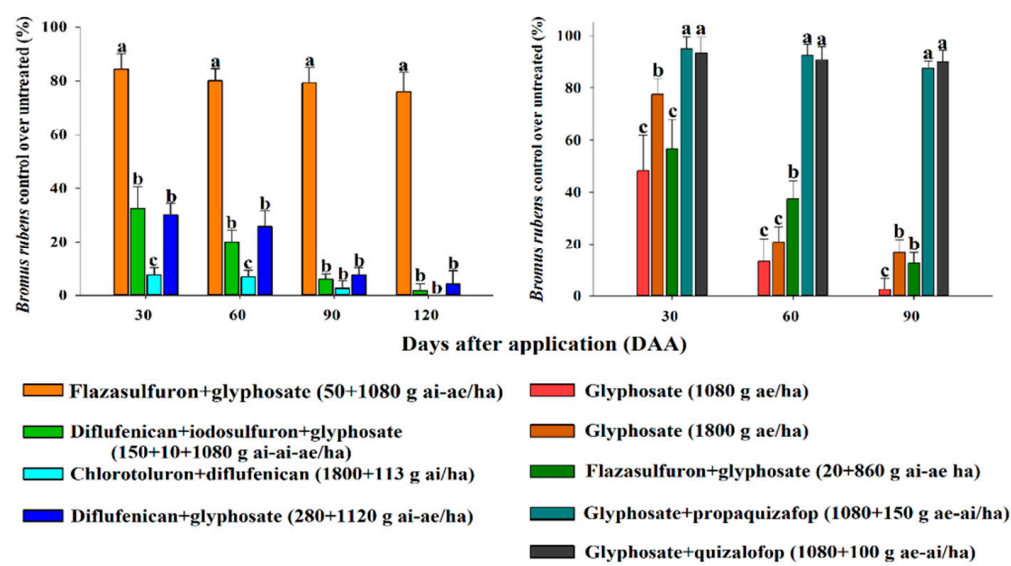

Figure 4. Percentage of control of Bromus rubens in pre-emergence and postemergence with different herbicides and days after treatment. The different letters in the measurements differed statistically in the LSD test (95\%). 

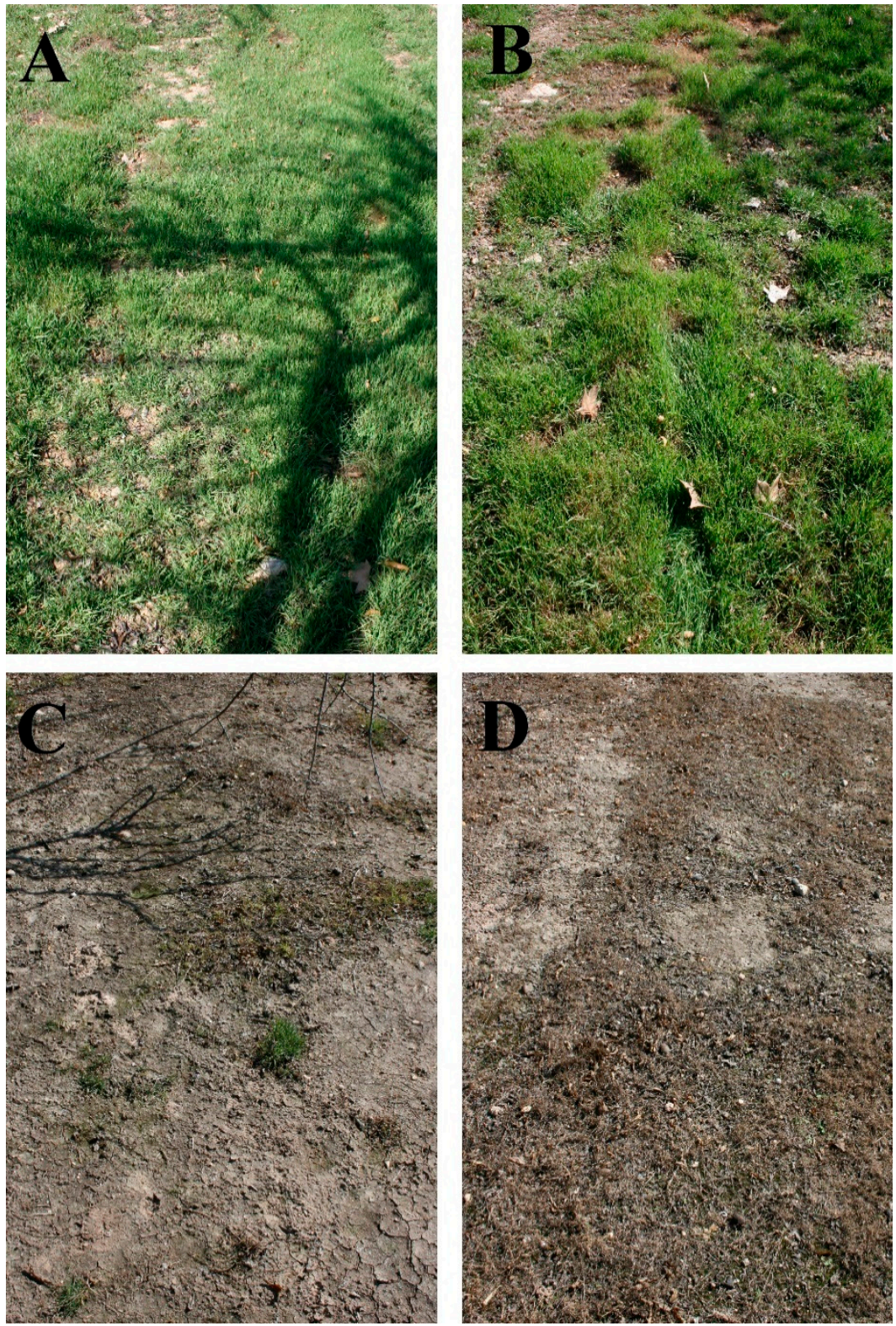

Figure 5. Percentage of Bromus rubens control. (A) Untreated, (B) glyphosate (1080 $\left.\mathrm{g}^{\mathrm{ae} \mathrm{ha}} \mathrm{ha}^{-1}\right)$, (C) flazasulfuron + glyphosate $\left(50+1080 \mathrm{~g}\right.$ ai/ae ha $\left.{ }^{-1}\right)$ and (D) glyphosate + propaquizafop $\left(1080+100 \mathrm{~g}\right.$ ae $\left./ \mathrm{ai} \mathrm{ha}^{-1}\right)$ at 90 days after application (DAA).

\section{Discussion}

Molecular markers have been successfully employed for genetic diversity and genetic characterization in a wide range of plant species. Particularly, SSR markers are very reliable and suitable for the study of genetic diversity between species of the same genus because of their transferability and power to detect closely related polymorphic individuals. It has been reported that, in general, cross-species transferability within genera is moderate to high $(50-100 \%$ success) [32,33]. In this work, we used seven SSRs developed in B. tectorum [25] to discriminate five Bromus species. All SSR markers were polymorphic and transferable to the five species. Although we could not genetically distinguish $\mathrm{R}$ and $\mathrm{S}$ populations of $B$. rubens, the seven SSRs were useful tools for discriminating between the Bromus species. Thus, the dendrogram constructed in this study revealed that the five Bromus species are genetically distinct from each other and the 20 populations collected in Andalusia belong to B. rubens. 
In contrast, the rapid screening using the leaf disc shikimic acid accumulation allowed us to separate glyphosate- $\mathrm{R}$ and $-\mathrm{S}$ populations. In our study, the Br1 population accumulated a higher shikimic acid compared to Br4, Br5, Br6, Br7, Br8, Br9, Br10, Br12, Br13, Br14, Br15, Br16, Br17, Br18, Br19, and Br20 (Figure 2). These results indicate low sensibility to glyphosate due to no interaction between herbicide and its target site (EPSPS). These different patterns have been shown in different grasses, such as Chloris spp. [34-38] and Hordeum spp. [29,39].

Glyphosate field doses recommended for the control of weeds in Southern Spain under field conditions (1080 $\mathrm{g}_{\text {ae ha }}{ }^{-1}$ ) can control S (Br1, Br3, and Br11) B. rubens populations $\left(\mathrm{LD}_{50}\right.$ between 229.87 to $563.46 \mathrm{~g}_{\text {ae }} \mathrm{ha}^{-1}$ ). However, $\mathrm{R}$ populations required greater field doses than those used by farmers (Table 3). These results are supported by the definition of Herbicide Resistance Action Committee (HRAC), which defines tolerant and/or resistant plants as those that survive higher doses of glyphosate than those usually used by farmers [13]. However, this definition is very subjective since there are countries where glyphosate doses are lower than in others; therefore, a weed may be resistant in one country but not in another $[15,29,34,35,37,39]$ (Figure 3). The high RF and low accumulation of shikimic acid observed in the different $\mathrm{R}$ B. rubens are in agreement with those plants that have acquired resistance to the addition of more than one resistance mechanism, which could be a non-target site (NTSR) and/or mechanism of resistance to the target site (TSR). This scenario has been demonstrated in other grass weed species [40-42]. Our results conclude that RF values also separated the 20 populations of $B$. rubens into one group $-S$ and another much larger group (17 populations) of glyphosate-R (Figure 3). Therefore, we can observe that all $\mathrm{R}$ populations meet the requirements of RF values greater than 4 to be considered resistant [29,35].

Overall, this study revealed different levels of G-R in B. rubens harvested from different agricultural areas in Southern Spain, where there are a variety of soils and climatic differences. The proposed response of herbicides between different places depends on local ecological factors, such as a variation in climate, soil type, tillage practices, types of crops, and fertilizers, among others. $[34,43,44]$. Additionally, the use of different glyphosate formulations and the dose rate, application time per year, application technique used by farmers, and environmental conditions could respond to the differences found $[45,46]$. In addition, an increase in relative humidity and temperature increases the absorption, translocation, and effectiveness of glyphosate in many species of grass weeds, which could help us understand the differences between populations of B. rubens [47,48].

Only in some cases did differences in plant architecture or total leaf surface area contribute to a plant's sensitivity to glyphosate, as a change in the fitness of R versus $S$ plants can alter the growth of $R$ plants to reduce glyphosate retention [49-51]. Our results determined that the $\mathrm{R}$ and $\mathrm{S}$ populations of $B$. rubens did not exhibit differences in fitness and herbicide retention. In addition, glyphosate retention was similar to that found in other grass weeds, such as Hordeum murinum [29], among others.

When a weed begins to predominate due to a lack of control, it is necessary to carry out a study of alternative herbicides that will help in short- and medium-term management in the field. The study must include pre-emergent or postemergence application alternatives [52]. We found that for pre-emergent applications, the best results were obtained when mixing glyphosate and flazasulfuron (Figure 5C); it is obvious that the control of $B$. rubens offered by this mixture is attributed to flazasulfuron (an ALS herbicide). Similar results were obtained by Reeves and Hoyle [53], where the application of flazasulfuron resulted in acceptable controls against Poa anua up to 133 DAA. The application of postemergence herbicides used alone or in combination with pre-emergence herbicides is very frequent in plantations, as they help to carry out fewer applications per year. As for postemergence applications, in this work, the best results were obtained with the mixture of glyphosate plus propaquizafop or quizalofop (Figure 5D). ACCase herbicides have multiple advantages of being applied in postemergence. However, they are specific to grass weeds, such 
as B. rubens, and have excellent selectivity in crops [54]. Other studies in B. tectorum and $B$. japonicus found that glyphosate is effective in reducing biomass [55-57].

There is little information related to the application of graminicides for the control of Bromus sp. [58,59]. Ball et al. [58] found better efficacy of quizalofop and fluazifop than sethoxydim. Our results are promising for the benefit of farmers, both in pre- and postemergence applications. The key to success in weed control is to alternate modes of action, use the recommended dose and apply it in a suitable phenological state [60]. These tools must be used correctly to preserve their efficacy. In addition, farmers must learn weed management lessons and use other nonchemical measures that can help decrease the seed bank and seedling density in the field.

\section{Conclusions}

The results confirmed the resistance of $B$. rubens populations to glyphosate collected in Southern Spain. This research is the first scientific report with established resistance parameters of G-R in B. rubens from Spain. Furthermore, field trials demonstrated that, at the moment, there are alternative herbicides to control these $\mathrm{R}$ populations. Flazasulfuron (pre-emergence herbicide) in the tank mix with glyphosate (postemergence herbicide), propaquizafop, or quizalofop (postemergence herbicides) plus glyphosate increase the control of B. rubens. Nowadays, we are aware of that fact and effective research is in progress to characterize resistance mechanisms NTSR or TSR involving these populations.

Author Contributions: Conceptualization, J.G.V.-G., P.C., H.E.C.-H., T.M., C.P.-B. and R.D.P.; methodology, J.G.V.-G., H.E.C.-H. and C.P.-B.; validation, J.G.V.-G., P.C., H.E.C.-H., T.M., C.P.-B. and R.D.P.; formal analysis, J.G.V.-G., P.C., H.E.C.-H., and C.P.-B.; investigation, J.G.V.-G., P.C., H.E.C.-H., T.M., C.P.-B. and R.D.P.; resources, R.D.P.; data curation, J.G.V.-G., P.C. and C.P.-B.; writing-original draft preparation, writing-review and editing, visualization, J.G.V.-G., P.C., H.E.C.-H., T.M., C.P.-B. and R.D.P.; supervision, P.C., T.M. and R.D.P.; project administration and funding acquisition, R.D.P. All authors have read and agreed to the published version of the manuscript.

Funding: This research has been supported by Asociación de Agroquímicos y Medio Ambiente and project ref PO 4513358935 by Bayer CropScience.

Institutional Review Board Statement: Not applicable.

Informed Consent Statement: Not applicable.

Data Availability Statement: Data sharing not applicable.

Acknowledgments: The authors are grateful to Rafael Zamorano García for their technical help.

Conflicts of Interest: The authors declare no conflict of interest.

\section{References}

1. Busi, R.; Powles, S.B.; Beckie, H.J.; Renton, M. Rotations and mixtures of soil-applied herbicides delay resistance. Pest Manag. Sci. 2020, 76, 487-496. [CrossRef] [PubMed]

2. Holländer, H.; Amrhein, N. The site of the inhibition of the shikimate pathway by glyphosate. Plant Physiol. 1980, 66, 823-829. [CrossRef]

3. Steinrücken, H.C.; Amrhein, N. The herbicide glyphosate is a potent inhibitor of 5-enolpyruvylshikimic acid-3-phosphate synthase. Biochem. Biophys. Res. Commun. 1980, 94, 1207-1212. [CrossRef]

4. Sammons, R.D.; Gaines, T.A. Glyphosate resistance: State of knowledge. Pest Manag. Sci. 2014, 70, 1367-1377. [CrossRef] [PubMed]

5. Duke, S.O.; Powles, S.B. Glyphosate: A once-in-a-century herbicide. Pest Manag. Sci. 2008, 64, 319-325. [CrossRef]

6. Powles, S.B.; Yu, Q. Evolution in ction: Plants resistant to herbicides. Annu. Rev. Plant Biol. 2010, 61, 317-347. [CrossRef]

7. Délye, C.; Jasieniuk, M.; Le Corre, V. Deciphering the evolution of herbicide resistance in weeds. Trends Genet. 2013, 29, 649-658. [CrossRef] [PubMed]

8. Owen, M.D. Weed species shifts in glyphosate-resistant crops. Pest Manag. Sci. 2008, 64, 377-387. [CrossRef]

9. Heap, I. Global perspective of herbicide-resistant weeds. Pest Manag. Sci. 2014, 70, 1306-1315. [CrossRef] [PubMed]

10. Gaines, T.A.; Duke, S.O.; Morran, S.; Rigon, C.A.G.; Tranel, P.J.; Küpper, A.; Dayan, F.E. Mechanisms of evolved herbicide resistance. J. Biol. Chem. 2020, 295, 10307-10330. [CrossRef] 
11. Owen, M.D.; Zelaya, I.A. Herbicide-resistant crops and weed resistance to herbicides. Pest Manag. Sci. 2005, 61, 301-311. [CrossRef]

12. Powles, S.B.; Lorraine-Colwill, D.F.; Dellow, J.J.; Preston, C. Evolved resistance to glyphosate in rigid ryegrass (Lolium rigidum) in Australia. Weed Sci. 1998, 46, 604-607. [CrossRef]

13. Heap, I. International Survey of Herbicide Resistant Weeds. Available online: http://www.weedscience.org (accessed on 15 January 2020).

14. Malone, J.M.; Morran, S.; Shirley, N.; Boutsalis, P.; Preston, C. EPSPS gene amplification in glyphosate-resistant Bromus diandrus. Pest Manag. Sci. 2016, 72, 81-88. [CrossRef] [PubMed]

15. Davies, L.R.; Hull, R.; Moss, S.; Neve, P. The first cases of evolving glyphosate resistance in UK poverty brome (Bromus sterilis) populations. Weed Sci. 2019, 67, 41-47. [CrossRef]

16. Acedo, C.; Llamas, F. The Genus Bromus L. (Poaceae) in the Iberian Peninsula; J. Cramer: Berlín-Stutgart, Germany, 1999; ISBN 9783443780043.

17. Smith, P. Bromus. In Flora Europea; Tutin, T.G., Heywood, V.H., Burges, N.A., Moore, D.M., Valentine, D.H., Walters, S.M., Webb, D.A., Eds.; Cambridge University Press: Cambridge, UK, 1980; pp. 182-189.

18. Fortune, P.M.; Pourtau, N.; Viron, N.; Ainouche, M.L. Molecular phylogeny and reticulate origins of the polyploid Bromus species from section Genea (Poaceae). Am. J. Bot. 2008, 95, 454-464. [CrossRef]

19. Salo, L.F. Population dynamics of red brome (Bromus madritensis subsp. rubens): Times for concern, opportunities for management. J. Arid Environ. 2004, 57, 291-296. [CrossRef]

20. Rivas Ponce, M.A. Nuevos datos para la diagnosis de Bromus rubens L. y B. madritensis L. (Poaceae). Lagascalia 1988, 15, 89-93.

21. Horn, K.J.; Bishop, T.B.B.; Clair, S.B.S. Precipitation timing and soil heterogeneity regulate the growth and seed production of the invasive grass red brome. Biol. Invasions 2017, 19, 1339-1350. [CrossRef]

22. Francia Martínez, J.R.; Durán Zuazo, V.H.; Martínez Raya, A. Environmental impact from mountainous olive orchards under different soil-management systems (SE Spain). Sci. Total Environ. 2006, 358, 46-60. [CrossRef] [PubMed]

23. Fernández-Moreno, P.T.; Alcántara-de la Cruz, R.; Smeda, R.J.; De Prado, R. Differential Resistance Mechanisms to Glyphosate Result in Fitness Cost for Lolium perenne and L. multiflorum. Front. Plant Sci. 2017, 8, 1796. [CrossRef]

24. Pujadas-Salva, A. Flora Arvense y Ruderal de la Provincia de Córdoba; University of Cordoba: Córdoba, Spain, 1986.

25. Ramakrishnan, A.P.; Coleman, C.E.; Meyer, S.E.; Fairbanks, D.J. Microsatellite markers for Bromus tectorum (cheatgrass). Mol. Ecol. Notes 2002, 2, 22-23. [CrossRef]

26. Zadoks, J.C.; Chang, T.T.; Konzak, C.F. A decimal code for the growth stages of cereals. Weed Res. 1974, 14, 415-421. [CrossRef]

27. Schuelke, M. An economic method for the fluorescent labeling of PCR fragments. Nat. Biotechnol. 2000, 18, 233-234. [CrossRef] [PubMed]

28. Rohlf, F.J. NTSYS-pc Numerical Taxonomy and Multivariate Analysis System. Version 2.02; Exeter Publications: Setauket, NY, USA, 1998.

29. Vázquez-García, J.G.; Castro, P.; Torra, J.; Alcántara-de la Cruz, R.; De Prado, R. Resistance evolution to EPSPS Inhibiting Herbicides in False Barley (Hordeum murinum) Harvested in Southern Spain. Agronomy 2020, 10, 992. [CrossRef]

30. González-Torralva, F.; Rojano-Delgado, A.M.; Luque de Castro, M.D.; Mülleder, N.; De Prado, R. Two non-target mechanisms are involved in glyphosate-resistant horseweed (Conyza canadensis L. Cronq.) biotypes. J. Plant Physiol. 2012, 169, 1673-1679. [CrossRef]

31. Ritz, C.; Baty, F.; Streibig, J.C.; Gerhard, D. Dose-response analysis using R. PLoS ONE 2015, 10, e0146021. [CrossRef]

32. O'Hanlon, P.C.; Peakall, R.; Briese, D.T. A review of new PCR-based genetic markers and their utility to weed ecology. Weed Res. 2000, 40, 239-254. [CrossRef]

33. Zhu, X.C.; Wu, H.W.; Raman, H.; Lemerle, D.; Stanton, R.; Burrows, G.E. Evaluation of simple sequence repeat (SSR) markers from Solanum crop species for Solanum elaeagnifolium. Weed Res. 2012, 52, 217-223. [CrossRef]

34. Ngo, T.D.; Malone, J.M.; Boutsalis, P.; Gill, G.; Preston, C. EPSPS gene amplification conferring resistance to glyphosate in windmill grass (Chloris truncata) in Australia. Pest Manag. Sci. 2018, 74, 1101-1108. [CrossRef] [PubMed]

35. Vázquez-García, J.G.; Golmohammadzadeh, S.; Palma-Bautista, C.; Rojano-Delgado, A.M.; Domínguez-Valenzuela, J.A.; CruzHipólito, H.E.; De Prado, R. New Case of False-Star-Grass (Chloris distichophylla) Population Evolving Glyphosate Resistance. Agronomy 2020, 10, 377. [CrossRef]

36. Bracamonte, E.R.; Fernández-Moreno, P.T.; Bastida, F.; Osuna, M.D.; Alcántara-de la Cruz, R.; Cruz-Hipolito, H.E.; De Prado, R. Identifying Chloris species from cuban citrus orchards and determining their glyphosate-resistance status. Front. Plant Sci. 2017, 8, 1977. [CrossRef] [PubMed]

37. Bracamonte, E.; da Silveira, H.M.; Alcántara-de la Cruz, R.; Domínguez-Valenzuela, J.A.; Cruz-Hipolito, H.E.; De Prado, R. From tolerance to resistance: Mechanisms governing the differential response to glyphosate in Chloris barbata. Pest Manag. Sci. 2018, 74, 1118-1124. [CrossRef]

38. Ngo, T.D.; Krishnan, M.; Boutsalis, P.; Gill, G.; Preston, C. Target-site mutations conferring resistance to glyphosate in feathertop Rhodes grass (Chloris virgata) populations in Australia. Pest Manag. Sci. 2017, 74, 1094-1100. [CrossRef]

39. Adu-Yeboah, P.; Malone, J.M.; Fleet, B.; Gill, G.; Preston, C. EPSPS gene amplification confers resistance to glyphosate resistant populations of Hordeum glaucum Stued (northern barley grass) in South Australia. Pest Manag. Sci. 2020, 76, 1214-1221. [CrossRef] [PubMed] 
40. Gaines, T.A.; Zhang, W.; Wang, D.; Bukun, B.; Chisholm, S.T.; Shaner, D.L.; Nissen, S.J.; Patzoldt, W.L.; Tranel, P.J.; Culpepper, A.S.; et al. Gene amplification confers glyphosate resistance in Amaranthus palmeri. Proc. Natl. Acad. Sci. USA 2010, 107, 1029-1034. [CrossRef]

41. Alcántara-de la Cruz, R.; Fernández-Moreno, P.T.; Ozuna, C.V.; Rojano-Delgado, A.M.; Cruz-Hipolito, H.E.; DomínguezValenzuela, J.A.; Barro, F; De Prado, R. Target and Non-target Site Mechanisms Developed by Glyphosate-Resistant Hairy beggarticks (Bidens pilosa L.) Populations from Mexico. Front. Plant Sci. 2016, 7, 1492. [CrossRef] [PubMed]

42. de Carvalho, L.B.; Costa Aguiar Alves, P.L.D.; González-Torralva, F.; Cruz-Hipolito, H.E.; Rojano-Delgado, A.M.; De Prado, R.; Gil-Humanes, J.; Barro, F.; Luque de Castro, M.D. Pool of Resistance Mechanisms to Glyphosate in Digitaria insularis. J. Agric. Food Chem. 2012, 60, 615-622. [CrossRef] [PubMed]

43. Jussaume, R.A.; Ervin, D. Understanding weed resistance as a wicked problem to improve weed management decisions. Weed Sci. 2016, 64, 559-569. [CrossRef]

44. Shaner, D.L.; Beckie, H.J. The future for weed control and technology. Pest Manag. Sci. 2014, 70, 1329-1339. [CrossRef]

45. Owen, M.D.K. Diverse approaches to herbicide-resistant weed management. Weed Sci. 2016, 64, 570-584. [CrossRef]

46. Bracamonte, E.; Fernández-Moreno, P.T.; Barro, F.; De Prado, R. Glyphosate-resistant Parthenium hysterophorus in the Caribbean Islands: Non target site resistance and target site resistance in relation to resistance levels. Front. Plant Sci. 2016, 7, 1845. [CrossRef]

47. Hatterman-Valenti, H.; Pitty, A.; Owen, M. Environmental effects on velvetleaf (Abutilon theophrasti) epicuticular wax deposition and herbicide absorption. Weed Sci. 2011, 59, 14-21. [CrossRef]

48. Nguyen, T.H.; Malone, J.M.; Boutsalis, P.; Shirley, N.; Preston, C. Temperature influences the level of glyphosate resistance in barnyardgrass (Echinochloa colona). Pest Manag. Sci. 2016, 72, 1031-1039. [CrossRef]

49. Brunharo, C.A.; Patterson, E.L.; Carrijo, D.R.; de Melo, M.S.; Nicolai, M.; Gaines, T.A.; Nissen, S.J.; Christoffoleti, P.J. Confirmation and mechanism of glyphosate resistance in tall windmill grass (Chloris elata) from Brazil. Pest Manag. Sci. 2016, 72, 1758-1764. [CrossRef]

50. Vila-Aiub, M.M.; Neve, P.; Roux, F. A unified approach to the estimation and interpretation of resistance costs in plants. Heredity 2011, 107, 386-394. [CrossRef] [PubMed]

51. Yanniccari, M.; Vila-Aiub, M.; Istilart, C.; Acciaresi, H.; Castro, A.M. Glyphosate resistance in perennial ryegrass (Lolium perenne L.) is associated with a fitness penalty. Weed Sci. 2016, 64, 71-79. [CrossRef]

52. Elezovic, I.; Datta, A.; Vrbnicanin, S.; Glamoclija, D.; Simic, M.; Malidza, G.; Knezevic, S.Z. Yield and yield components of imidazolinone-resistant sunflower (Helianthus annuus L.) are influenced by pre-emergence herbicide and time of post-emergence weed removal. Field Crop. Res. 2012, 128, 137-146. [CrossRef]

53. Reeves, J.; Hoyle, J. Late Pre-Emergent Control of Annual Bluegrass with Flazasulfuron \& Indaziflam. Kansas Agric. Exp. Stn. Res. Rep. 2016, 2. [CrossRef]

54. Kukorelli, G.; Reisinger, P.; Pinke, G. ACCase inhibitor herbicides-selectivity, weed resistance and fitness cost: A review. Int. J. Pest Manag. 2013, 59, 165-173. [CrossRef]

55. Cox, R.; Anderson, V. Increasing native diversity of cheatgrass-dominated rangeland through assisted succession. J. Range Manag. 2004, 57, 203-2010. [CrossRef]

56. Morris, C.; Morris, L.R.; Surface, C. Spring Glyphosate application for selective control of downy brome (Bromus tectorum L.) on Great Basin Rangelands. Weed Technol. 2016, 30, 297-302. [CrossRef]

57. Park, K.W.; Mallory-Smith, C.A. Physiological and molecular basis for ALS inhibitor resistance in Bromus tectorum biotypes. Weed Res. 2004, 44, 71-77. [CrossRef]

58. Ball, D.A.; Frost, S.M.; Bennett, L.H. ACCase-inhibitor herbicide resistance in downy brome (Bromus tectorum) in Oregon. Weed Sci. 2007, 55, 91-94. [CrossRef]

59. Brewster, B.D.; Spinney, R.L. Control of seedling grasses with postemergence grass herbicides. Weed Technol. 1989, 3, 39-43. [CrossRef]

60. Reinhardt Piskackova, T.A.; Reberg-Horton, C.; Richardson, R.J.; Jennings, K.M.; Leon, R.G. Integrating emergence and phenology models to determine windows of action for weed control: A case study using Senna obtusifolia. Field Crop. Res. 2020, $258,107959$. [CrossRef] 